\title{
Pengembangan Mobile Learning Berbasis Client Server Pada Mata Pelajaran Simulasi Digital
}

\author{
Jhon Veri ${ }^{1}$, Rini Sefriani ${ }^{2}$, Leo Aulia ${ }^{3}$, \\ Fakultas Keguruan dan Ilmu Pendidikan, Universitas Putra Indonesia 'YPTK' Padang \\ Email:,jhonveri@gmail.com,rinisefriani@upiyptk.ac.id, leoaulia38@gmail.com
}

\begin{abstract}
Abstrak
Penelitian ini bertujuan untuk mengetahui tingkat Validitas, Praktikalitas dan Efektifitas media pembelajaran Mobile Learning berbasis Client Server di SMK Negeri 9 Padang. Karena masih terbatasnya sumber belajar dan media pembelajaran dalam bentuk multimedia interaktif dengan kemasan mobile learning di SMKN 9 Padang . Penelitian menggunakan model pengembangan (Four-D model). Langkah-langkah pengembangannya adalah (1) Define, (2) Design, (3) Development, dan (4) Disseminate. Instrumen uji coba dilakukan pada 31 siswa di SMK N 9 Padang. Sampel dalaam penelitian in sebanyak 31 orang siswa. Hasil penelitian menunjukkan tingkat validitas diperoleh sebesar 82,17\% dengan interpretasi valid, tingkat praktikalitas sebesar 82,29\% yang berarti praktis digunakan dan untuk tingkat uji efektifitas sebesar 90,03 yang berarti sangat efektif digunakan media pembelajaran Mobile Learning Berbasis Client Server Pada Mata Pelajaran Simulasi Digital di SMKN 9 Padang.
\end{abstract}

Kata kunci : Client Server,Mobile Learning, Simulasi Digital

\begin{abstract}
This study aims to determine the level of Validity, Practicality and Effectiveness of Client Server-based Mobile Learning media in SMK Negeri 9 Padang. Because there are still limited learning resources and learning media in the form of interactive multimedia with mobile learning packaging at Padang Vocational High School 9. The study uses a development model (Four-D model). The development steps are (1) Define, (2) Design, (3) Development, and (4) Disseminate. The trial instrument was conducted on 31 students at Padang N 9 Vocational School. The sample in this study was 31 students. The results showed that the level of validity obtained was $82.17 \%$ with valid interpretations, the practicality level was $82.29 \%$, which meant that it was practically used and for the effectiveness test level of 90.03 , which meant that it was very effective to use the Learning Media Client Server Based Learning Media. Digital Simulation at SMKN 9 Padang.
\end{abstract}

Keywords: Client Server, Mobile Learning, Digital Simulation

\section{Pendahuluan}

Mata pelajaran Simulasi Digital (SIMDIG) adalah mata pelajaran yang diwajibkan di sekolah menengah kejuruan ( SMK). Simulasi Digital merupakan mata pelajaran yang sangat penting di SMK, hal ini dikarenakan mata pelajaran SIMDIG dipelajari disemua jurusan yang ada di SMK termasuk di SMKN 9 Padang. Berhasil atau tidaknya pembelajaran simulasi digital di sekolah salah satu nya di lihat dari hasil belajar yang di peroleh oleh siswa. Salah satu faktor penentu tercapainya tujuan pembelajaran adalah dengan adanya hasil belajar siswa yang baik. Hal ini belum ditunjukkan oleh hasil belajar yang dicapai oleh siswa pada mata pelajaran simuladi digital di SMKN 9 Padang. Karena masih banyaknya siswa yang memperoleh nilai SIMDIG yang berada di bawah KKM, dan antusias siswa untuk mengikuti pembelajaran belum maksimal. Permasalahan ini dikarenakan keterbatasan sumber belajar yang ada di sekolah, misalnya kurang lengkapnya buku penunjang pembelajaran di sekolah yang nantinya akan mampu meningkatkan hasil belajar siswa. Masih sangat terbatasnya media pembelajaran multimedia interaktif untuk mata pelajaran

Dikirim

Diterima

Diterbitkan

DOI
: 2019-03-27

: 2019-04-08

: 2019-04-08

: https://doi.org/10.29165/komtekinfo.v5i2 
simulasi digital dalam bentuk mobile learning. Oleh sebab itu Mobile Learning Berbasis Client Server di duga dapat membantu proses pembelajaran, dimana di dalam Mobile Learning Berbasis Client Server sudah terdapat materi berupa teori, gambar dan bentuk dapat diperlihatkan, video pembelajaran SIMDIG, dan yang paling penting adanya uji kompetensi yang berupa latihan dan dapat melihat seberapa jauh kemampuan siswa, yang dapat memusatkan perhatian siswa dalam belajar, dan tidak bosan dalam proses pembelajaran, karena dianggap pembelajaran lebih menarik dan memiliki variasi.

Media pembelajaran adalah suatu perantara dari sumber informasi ke penerima informasi, seperti video, televisi, komputer, dan sebagainya yang digunakan untuk menyalurkan informasi yang disampaikan Sanjaya[1] . Media pembelajaran tersebut menjadi sarana atau perantara dalam me-nyampaikan pelajaran. Definisi tersebut didukung oleh Smaldino, dkk. menyatakan bahwa media pembelajaran berfungsi untuk menyampaikan pelajaran antara siswa dan guru dalam proses pembelajaran dalam mencipta- kan pembelajaran secara efektif dengan mempengaruhi kondisi dan lingkungan belajar guna memfasilitasi guru dan siswa dalam menjalin komunikasi dan belajar. Media pembelajaran berperan sangat efektif dalam pembelajaran, baik materi teori maupun dalam prakteknya (Indra Wijaya) [2]. Pembelajaran yang interaktif akan membangkitkan keinginan dari dalam diri siswa untuk mengikuti pembelajaran di kelas Rini Sefriani[3] .

M-Learning merupakan salahsatu media pembelajaran yang memungkinkan pendidik menyampai- kan bahan ajar kepada peserta didik menggunakan media berbasis hand- phone. M-Learning memungkinkan peserta didik dapat melakukan kegiatan berupa materi pembelajaran, arahan dan informasi pembelajaran di mana pun dan kapan pun tidak terbatas ruang dan waktu. M-Learning juga mampu mengatasi keterbatasan alokasi waktu untuk materi tertentu. M- Learning juga mampu melatih peserta didik untuk belajar mandiri dari berbagai sumber yang disediakan. Hal ini sesuai dengan pendapat Yuniati [4]yang menyatakan bahwa peningkatkan perhatian siswa pada materi pembelajaran.

Berdasarkan penjelasan tersebut maka perlu dibuat dan dirancang media pembelajaran yang dikemas dalam bentuk mobile learning. Dengan harapan dapat nantinya menjadi media pembelajaran tambahan dalam pembelajaran simulasi digital sehingga mampu meningkatkan hasil belajar simulasi belajar siswa.

\section{Tinjauan Literatur}

\subsection{Media Pembelajaran}

Kata media berasal dari bahasa latin yaitu medius yang secara harfiah berarti tengah, perantara atau pengantar. Gerlach \& Ely (Arsyad, 2011)[5] mengatakan bahwa media apabila dipahami secara garis besar adalah manusia, materi atau kejadian yang membangun kondisi yang membuat siswa mampu memperoleh pengetahuan, keterampilan dan sikap. Penggunaan media pembelajran yang tepat akan dapat meningkatkan hasil belajar yang diharapkan, sesuai dengan yang dilakukan penelitian oleh Indra Wijaya[6]

2.2 Mobile Learning

M-learning adalah model pembelajaran yang memanfaatkan teknologi informasi dan komunikasi. Pada konsep pembelajaran tersebut m-learning membawa manfaat ketersediaan materi ajar yang dapat di akses setiap saat dan visualisasi materi yang menarik dan dapat diakses dari mana saja dan kapan saja. Mobile learning ( $M$ Learning) didefinisikan oleh Agnes dan John (2003:6) sebagai: "Mobile learning as taking place when the learner is not at a fixed, predetermined location, or when the learner takes advantage of the learning opportunities offered by mobile technologies"[7]

2.3 Android

Menurut Hermawan (2011:1), Android merupakan Operating System (OS) Mobile yang tumbuh ditengah $O S$ lainnya yang berkembang dewasa ini. $O S$ lainnya 
seperti Windows Mobile, i-Phone OS, Symbian, dan masih banyak lagi. Sugeng Purwantoro, Heni Rahmawati dan Achmad Tharmizi (2013: 177) mengatakan "Android merupakan suatu software (perangkat lunak) yang digunakan pada mobile device (perangkat berjalan) yang meliputi sistem operasi, middleware dan aplikasi inti". Android menurut Satyaputra dan Aritonang (2014: 2) adalah sebuah sistem operasi untuk smartphone dan tablet. Sistem operasi dapat diilustrasikan sebagai jembatan antara piranti (device) dan penggunaannya, sehingga pengguna dapat berinteraksi dengan device-nya dan menjalankan aplikasi-aplikasi yang tersedia pada device. Referensi lain ditemukan bahwa Arif Akbarul Huda (2013: 1-5) berpendapat mengenai Android merupakan system operasi berbasis Linux yang khusus untuk perangkat bergerak seperti smartphone atau tablet

2.4 Mata Pelajaran SIMDIG

Mata pelajaran Simulasi Digital merupakan salah satu dari mata diklat yang masuk kedalam ranah kognitif yang terdapat dalam kurikulum SMK 2013 disebut dengan program adaptif, program adaptif berfungsi untuk membentuk peserta didik sebagai individu agar memiliki dasar yang kuat untuk berkembang dan mampu menyesuaikan diri dengan perubahan.

\section{Metodologi}

\subsection{Jenis Penelitian}

Penelitian ini menggunakan penelitian dan pengembangan atau biasa disebut dengan $R \& D$ (research and development),yaitu metode penelitian yang digunakan untuk menghasilkan produk tertentu, dan menguji keefektifan produk tersebut.

Model pengembangan dalam penelitian ini menggunakan four-D yang terdiri dari 4 tahap yaitu Define (Pendefinisian), Design (Perancangan), Develop (Pengembangan) dan Dessminate (penyebaran)".

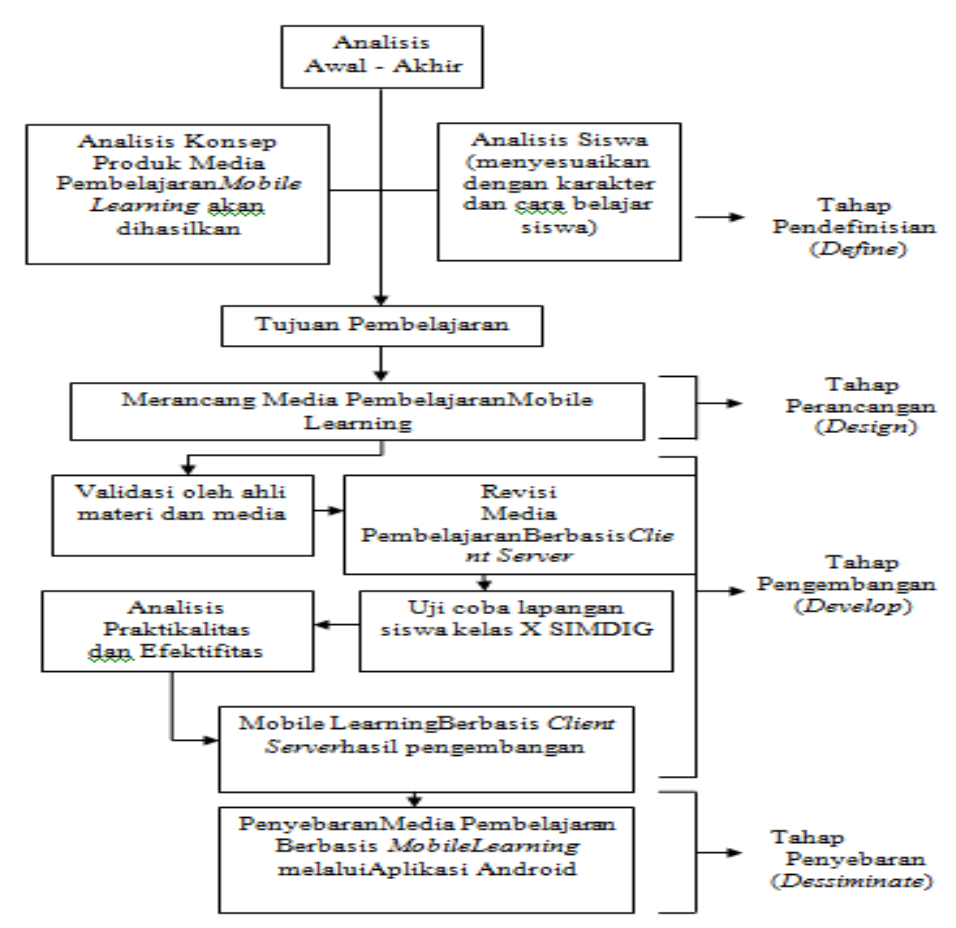

Gambar 1 Model Pengembangan Four-D 


\subsection{Subjek Penelitian}

Penelitian media pembelajaran Mobile Learning di fokuskan pada mata pelajaran Simulasi Digital (SIMDIG). Mobile Learning sebagai sumber belajar pada siswa kelas X SMK Negeri 9 Padang yang berjumlah 31 orang. Jenis data yang diambil dalam penelitian ini adalah data primer. Data pertama berupa hasil validasi Mobile Learning Berbasis Client Server yang diberikan oleh validator. Data kedua diperoleh dari pelaksanaan uji coba Mobile Learning Berbasis Client Server.

\subsection{Instrumen Penelitian}

1. Instrumen Kevalidan

Instrumen kevalidan digunakan untuk mengetahui apakah Mobile Learning Berbasis Client Server yang telah dirancang valid atau tidak.

Tabel 1. Kisi Kisi Angket Validator

\begin{tabular}{|c|l|c|c|}
\hline No & \multicolumn{1}{|c|}{ Indikator } & Item & Jumlah \\
\hline 1 & Kelayakan Isi. & 1 & 5 \\
\hline 2 & Komponen Kebahasaan & 6 & 4 \\
\hline 3 & Komponen Penyajian & 10 & 7 \\
\hline 4 & KomponenKegrafikan. & 17 & 4 \\
\hline \multicolumn{3}{|c|}{ Total Item } & $\mathbf{2 0}$ \\
\hline
\end{tabular}

Sumber :Hastuti, dkk (2015:115)

Untuk mengubah data kualitatif ke bentuk kuantitatif, maka angket selain di beri alternatif jawaban masing-masing mempunyai bobot dan skor dari setiap jawaban dari pernyataan dapat dilihat pada tabel berikut;

Tabel 2. Penilaian Jawaban

\begin{tabular}{|l|c|c|}
\hline \multicolumn{1}{|c|}{ Pilihan } & Keterangan & Bobot \\
\hline Sangat Setuju & SS & 5 \\
\hline Setuju & S & 4 \\
\hline Kurang Setuju & KS & 3 \\
\hline Tidak Setuju & TS & 2 \\
\hline Sangat Tidak Setuju & STS & 1 \\
\hline \multicolumn{2}{|c|}{ Sumber : Sugiyono (2014: 93) }
\end{tabular}

2. Intrumen Kepraktisan

Setelah instrument dinyatakan valid oleh validator, selanjutnya beberapa instrument tersebut digunakan untuk uji kepraktisan.

Tabel 3. Kisi-Kisi Angket Praktikalitas

\begin{tabular}{|c|l|c|c|}
\hline No & \multicolumn{1}{|c|}{ Indikator } & Item & Jumlah \\
\hline 1 & Keadaan Penggunaan. & 1 & 8 \\
\hline 2 & Efektifitas Waktu Pembelajaran. & 9 & 5 \\
\hline 3 & Manfaat & 14 & 5 \\
\hline \multicolumn{2}{|c|}{ Total Item } & $\mathbf{1 8}$ \\
\hline
\end{tabular}

Sumber : Riza \& Handayani (2014: 125)

Instrumen yang digunakan disusun menurut pola skala dalam bentuk kontiniu yang terdiri dari lima kategori dan pernyataan angket bersifat positif.

Tabel 4. Penilaian Jawaban

\begin{tabular}{|l|c|c|}
\hline \multicolumn{1}{|c|}{ Pilihan } & Keterangan & Bobot \\
\hline Sangat Setuju & SS & 5 \\
\hline Setuju & S & 4 \\
\hline
\end{tabular}


3. Instrumen Keefektifan

\begin{tabular}{|l|c|c|}
\hline Kurang Setuju & KS & 3 \\
\hline Tidak Setuju & TS & 2 \\
\hline Sangat Tidak Setuju & STS & 1 \\
\hline
\end{tabular}

Sumber : Sugiyono (2014:93)

Cara pengujian keefektifan Mobile Learning Berbasis Client Server digunakan Angket .Untuk mengetahui kemampuan belajar siswa, siswa menjawab soal Angket.Soal Angket diberikan setelah siswa mengikuti proses pembelajaran dengan Mobile Learning Berbasis Client Server.

\begin{tabular}{|c|l|c|c|}
\hline No & \multicolumn{1}{|c|}{ Indikator } & No Item & Jumlah \\
\hline 1 & Senang Belajar. & 1 & 7 \\
\hline 2 & $\begin{array}{l}\text { Adanya Bahan AjarYang } \\
\text { Menarik Dalam Belajar. }\end{array}$ & 8 & 5 \\
\hline
\end{tabular}

Teknik Analisa Data

a) Analisis Uji Validitas Mobile Learning Berbasis Client Server Memberikan skor jawaban dengan kriteria berdasarkan skala Likert yang dimodifikasi oleh Sugiyono [8] yaitu :

Tabel 6. Penilaian Jawaban validitas

\begin{tabular}{|l|c|c|}
\hline \multicolumn{1}{|c|}{ Pilihan } & Keterangan & Bobot \\
\hline Sangat Setuju & SS & 5 \\
\hline Setuju & S & 4 \\
\hline Kurang Setuju & KS & 3 \\
\hline Tidak Setuju & TS & 2 \\
\hline Sangat Tidak Setuju & STS & 1 \\
\hline
\end{tabular}

Sumber : Sugiyono $(2014: 135)$

b) Menentukan skor tertinggi

Skor tertinggi $=$ jumlah validator $\mathrm{x}$ jumlah item pertanyaan $\mathrm{x}$ skor maksimum.

c) Menentukan jumlah skor dari masing-masing validator dengan menjumlahkan semua skor yang di peroleh dari masing-masing indikator.

d) Menentukan skor yang diperoleh dengan menjumlahkan skor dari masing-masing validator.

e) Penentuan nilai validitas dimodifikasi dari Purwanto (2010:102) sebagai berikut: $N P=\frac{R}{S M} \times 100$.

Keterangan :

$\mathrm{NP}=$ Nilai persen yang dicari atau yang diharapkan

$\mathrm{R}=$ = Skor mentah yang diperoleh siswa

$\mathrm{SM}=$ Skor Maksimum ideal dari tes yang bersangkutan

$100=$ Bilangan Tetap

f) Memberikan penilaian validitas dengan kriteria yang dimodifikasi dari Purwanto (2010 : 82) berikut ini :

Tabel 7. Klasifikasi Aspek Penilaian Validitas

\begin{tabular}{|c|c|c|}
\hline No & Nilai & Aspek yang Dinilai \\
\hline 1 & $90 \%-100 \%$ & Sangat Valid \\
\hline 2 & $80 \%-89 \%$ & Valid \\
\hline 3 & $65 \%-79 \%$ & Cukup Valid \\
\hline 4 & $55 \%-64 \%$ & Kurang Valid \\
\hline 5 & $\leq 54 \%$ & Tidak Valid \\
\hline
\end{tabular}

Sumber : Purwanto (2010:82)

g) Kemudian menentukan nilai distribusi frekuensi validitas yang dimodifikasi dari Prof. Dr. H. Agus I. Irianto berikut ini: 


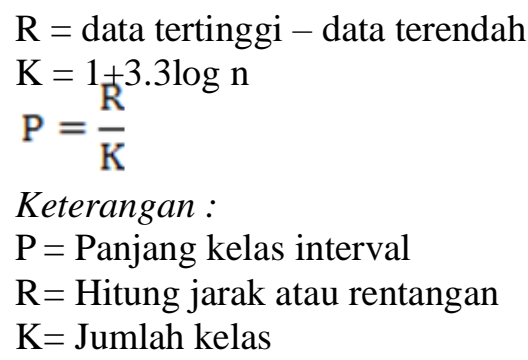

1. Analisis Uji Praktikalitas Mobile Learning Berbasis Client Server

Data uji praktikalitas penggunaan Mobile Learning Berbasis Client Server dianalisis dengan menggunakan rumus yang dimodifikasi dari Purwanto (2010: 102) berikut ini:

$$
\begin{aligned}
& \mathrm{NP}=\frac{\mathrm{R}}{\mathrm{SM}} \times 100 . \\
& \text { Keterangan : } \\
& \mathrm{NP} \quad=\text { Nilai persen yang dicari atau yang diharapkan } \\
& \mathrm{R} \quad=\text { Skor mentah yang diperoleh siswa } \\
& \mathrm{SM} \quad=\text { Skor Maksimum ideal dari tes yang bersangkutan } \\
& 100 \quad=\text { Bilangan Tetap }
\end{aligned}
$$

Setelah presentase diperoleh, dilakukan pengelompokkan sesuai kriteria yang dimodifikasi dari Purwanto (2010 : 103) berikut ini :

Tabel 8. Penilaian Praktikalitas

\begin{tabular}{|l|c|c|}
\hline No & Nilai & Aspek Yang Dinilai \\
\hline 1 & $86 \%-100 \%$ & Sangat Praktis \\
\hline 2 & $76 \%-85 \%$ & Praktis \\
\hline 3 & $60 \%-75 \%$ & Cukup Praktis \\
\hline 4 & $55 \%-59 \%$ & Kurang Praktis \\
\hline 5 & $\leq 54 \%$ & Tidak Praktis \\
\hline
\end{tabular}

2. Analisis Efektifitas Mobile Learning Berbasis Client Server

Data angket efektifitas diperoleh dengan cara menghitung skor siswa yang menjawab masing-masing item sebagaimana terdapat pada angket. Data tersebut dianalisis dengan teknik persentase yang dinyatakan oleh Purwanto (2010 : 102) sebagai berikut :

$$
\begin{aligned}
& \mathrm{NP}=\frac{\mathrm{R}}{\mathrm{SM}} \times 100 . \\
& \text { Keterangan : } \\
& \mathrm{NP} \quad=\text { Nilai persen yang dicari atau yang diharapkan } \\
& \mathrm{R} \quad=\text { Skor mentah yang diperoleh siswa } \\
& \mathrm{SM} \quad=\text { Skor Maksimum ideal dari tes yang bersangkutan } \\
& 100 \quad=\text { Bilangan Tetap }
\end{aligned}
$$
berikut :

Hasil yang diperoleh di interprestasikan dengan menggunakan kriteria sebagai

Tabel 9. Penilaian Efektivitas

\begin{tabular}{|l|c|c|}
\hline No & Nilai & Aspek Yang Dinilai \\
\hline 1 & $86 \%-100 \%$ & Sangat Baik \\
\hline 2 & $76 \%-85 \%$ & Baik \\
\hline 3 & $60 \%-75 \%$ & Cukup \\
\hline 4 & $55 \%-59 \%$ & Kurang \\
\hline 5 & $\leq 54 \%$ & Kurang Baik \\
\hline
\end{tabular}

\subsection{Rancangan Interface}


Desain user interface merupakan desain tampilan sistem yang akan dibuat, mulai dari desain input dan desain ouput.

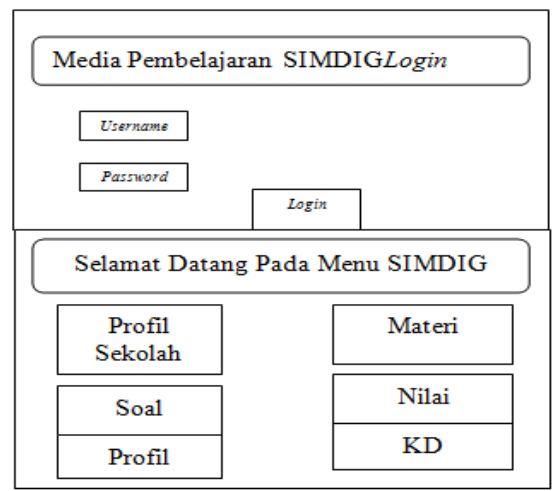

Gambar 2. Desain Form halaman Home

\section{Hasil dan Diskusi}

4.1 Hasil Rancangan Tampilan

1. Halaman Home

Home yang mengambarkan tampilan awal saat Mobile Learning Berbasis Client Server
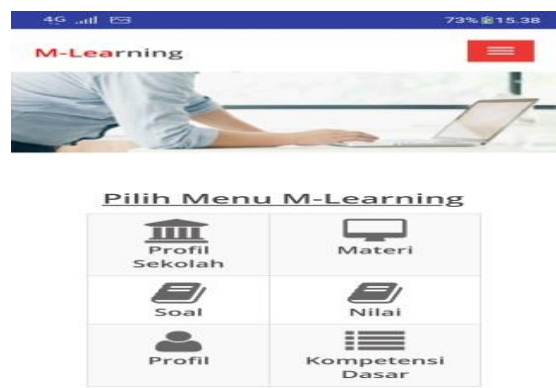

\subsection{Analisa Data}

Gambar 5. Halaman Home

\section{Uji Validasi}

Uji validitas dilakukan oleh 3 orang validator ahli media. Penilaian dari validator untuk media pembelajaran SIMDIG di tinjau dari aspek (1) Kelayakan isi: 89,00\%; (2) Komponen Kebahasaan: 93.00\%; (3) Komponen Penyajian: 90,00\%; (4) Komponen Kegrafikan: $87,00 \%$. Secara keseluruhan penilaian uji validator terhadap media pembelajaran Sistem Komputer sebesar 83,45\%, Secara keseluruhan penilaian uji validator terhadap mobile learning berbasisclient server sebesar $82,17 \%$, sehingga mobile learning berbasisclient server tersebut bisa dikatakan valid digunakan siswa untuk pembelajaran simulasi digital.

Tabel 10. Distribusi Frekuensi Skor Angket Validitas

\begin{tabular}{|l|c|c|c|}
\hline No & Kelas - Interval & F0 & \%F0 \\
\hline 1 & $80-85$ & 1 & 33,333 \\
\hline 2 & $86-91$ & 0 & 0 \\
\hline 3 & $92-97$ & 1 & 33,333 \\
\hline 4 & $98-103$ & 1 & 33,333 \\
\hline
\end{tabular}




\begin{tabular}{|c|c|c|c|}
\hline & Jumlah & $\mathbf{3}$ & $\mathbf{1 0 0}$ \\
\hline
\end{tabular}

Berdasarkan pada tabel diatas dapat dijelaskan untuk mencari perhitungan interval kelas dan panjang kelas.

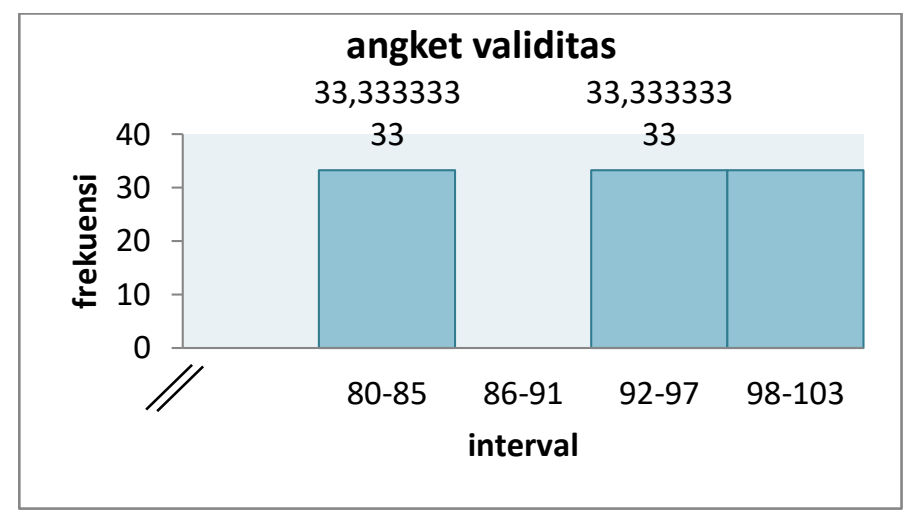

2. Uji Praktikalitas

Gambar 6.Histogram Angket Validitas

Uji coba praktikalitas yang dilakukan oleh 31 siswa. Penilaian mobile learning berbasis client server yang ditinjau dari aspek (1) Keadaan Penggunaan : 81,28\%; (2) Efektifitas Waktu Pembelajaran : 81,69\%; (3) Manfaat : 83,87\%. Secara keseluruhan penilaian uji praktikalitas terhadap mobile learning berbasis client serversebesar $82,29 \%$, sehingga media tersebut bisa dikatakan sangat praktis digunakan siswa untuk pembelajaran simulasi digital.

Tabel 11. Distribusi Frekuensi Skor Angket Praktikalitas
\begin{tabular}{|c|c|c|c|}
\hline No & Kelas Interval & $\mathrm{F}_{0}$ & $\% \mathrm{~F}_{0}$ \\
\hline 1 & $61-64$ & 2 & 6,451 \\
\hline 2 & $65-68$ & 1 & 3,225 \\
\hline 3 & $69-72$ & 1 & 3,225 \\
\hline 4 & $73-76$ & 3 & 9,677 \\
\hline 5 & $77-80$ & 5 & 16,129 \\
\hline 6 & $81-84$ & 17 & 54,838 \\
\hline 7 & $85-88$ & 2 & 6,451 \\
\hline & Jumlah & 31 & 100 \\
\hline
\end{tabular}

Sumber: Pengolahan Data Mandiri

Berdasarkan pada tabel tersebut dapat dijelaskan untuk mencari perhitungan interval kelas dan panjang kelas. 


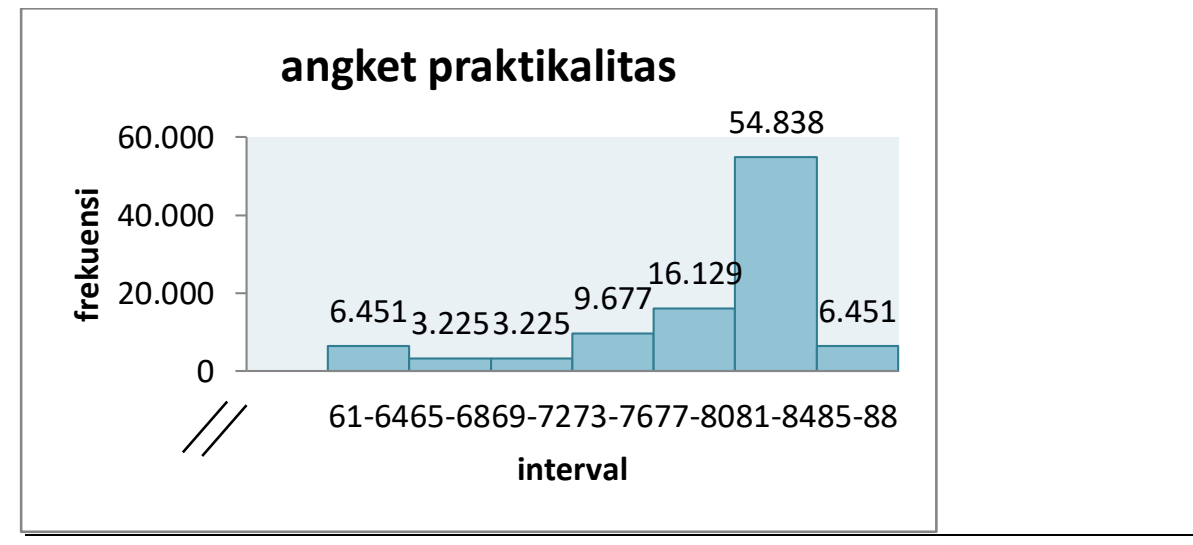

Gambar 7. Histogram Angket Praktikalitas

\section{Uji Efektivitas}

Uji efektivitas penilaian dilakukan oleh 31 orang siswa. Penilian mobile learning berbasis client server Data efektifitas Media Pembelajaran berbasis android melalui uji coba test soal efektifitas 31 siswa dengan jumlah 12 butir penyataan dilihat nilai efektifitas 90,63\%dapat dikatakan tingkat efektifitas mobile learning berbasis client server dinyatakan Sangat Baik digunakan untuk Kelas X di SMK Negeri 9 Padang tahun ajaran 2018/2019, sesuai dengan teori yang dikemukakan oleh Purwanto (dalam Cesaria \& Fitri 2010:96).

Tabel 12. Distribusi Frekuensi Skor Angket Efektifitas

\begin{tabular}{|c|c|c|c|}
\hline No & Kelas Interval & $\mathbf{f}_{\mathbf{0}}$ & $\mathbf{\% f}_{\mathbf{0}}$ \\
\hline 1 & $48-49$ & 7 & 22,580 \\
\hline 2 & $50-51$ & 2 & 6,451 \\
\hline 3 & $52-53$ & 5 & 16,129 \\
\hline 4 & $54-55$ & 3 & 9,677 \\
\hline 5 & $56-57$ & 4 & 12,903 \\
\hline 6 & $58-59$ & 2 & 6,451 \\
\hline 7 & $60-61$ & 8 & 25,806 \\
\hline & Jumlah & $\mathbf{3 1}$ & $\mathbf{1 0 0}$ \\
\hline
\end{tabular}

Sumber: Pengolahan Data Mandiri

Berdasarkan pada tabel diatas dapat dijelaskan untuk mencari perhitungan interval kelas dan panjang kelas. 


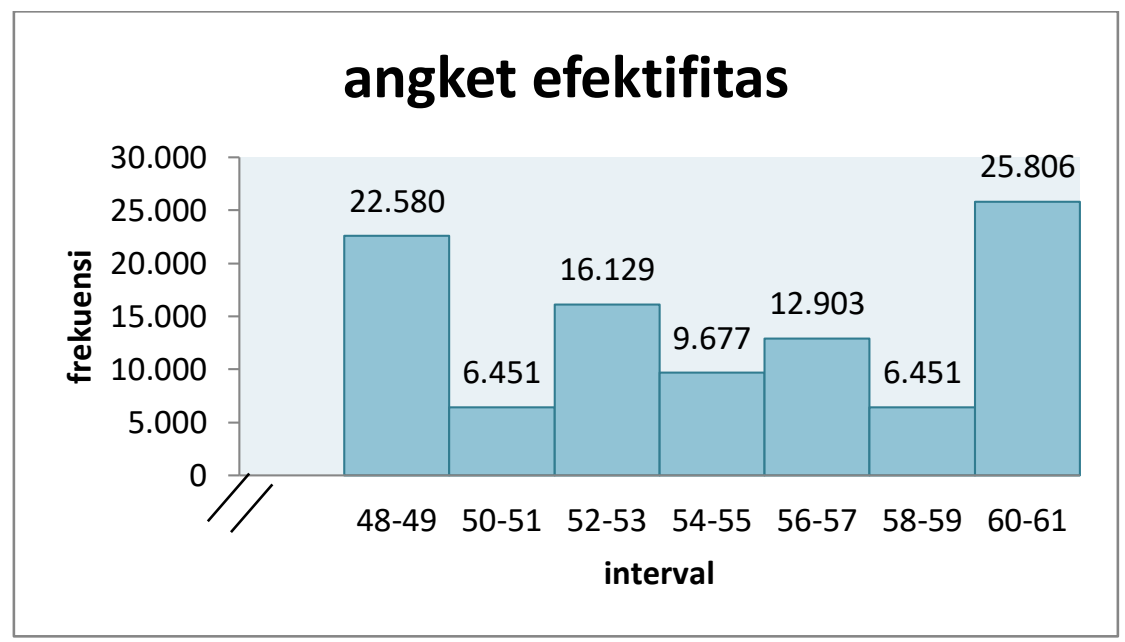

Gambar 8. Histogram Angket Efektifitas

\subsection{Pembahasan}

Perancangan dan pembuatan Mobile learning berbasis client sever pada mata pelajaran Simulasi Digital kelas X SMKN 9 Padang yang telah dibuat kemudian dilakukan validasi untuk mengetahui kelayakan media tersebut. Setelah mobile learning di validasi kemudian mobile learning di uji cobakan kepada siswa dalam bentuk uji coba Praktikalitas dan efektifitas. Hasil penelitian menunjukkan tingkat validitas diperoleh sebesar $82,17 \%$ dengan interpretasi valid, tingkat praktikalitas sebesar $82,29 \%$ yang berarti praktis digunakan dan untuk tingkat uji efektifitas sebesar 90,03 yang berarti sangat efektif digunakan media pembelajaran Mobile Learning Berbasis Client Server Pada Mata Pelajaran Simulasi Digital di SMKN 9 Padang

Tabel 13. Hasil uji coba Aplikasi Android

\begin{tabular}{|c|c|c|}
\hline Uji & Presentase & Keterangan \\
\hline Validasi & $82,17 \%$ & Valid \\
\hline Praktikalitas & $82,29 \%$ & Sangat Praktis \\
\hline Efektifitas & $90,63 \%$ & Sangat Baik \\
\hline
\end{tabular}

\section{Kesimpulan dan Saran}

1. Kesimpulan

a. Kevalidan oleh penilaian uji validator terhadap perancangan dan pembuatan Mobile Learning berbasis client sever pada mata pelajaran Simulasi Digital sebesar $82,17 \%$, sehingga tingkat validitas dapat di interprestasikan Valid digunakan.

b. Kepraktisan terhadap perancangan dan pembuatan Mobile Learning berbasis client sever pada mata pelajaran Simulasi Digital sebesar 82,29\%, sehingga tingkat praktikalitasnya dapat di interprestasikan sangat praktis digunakan.

c. Keefektifan terhadap perancangan dan pembuatan Mobile Learning berbasis client sever pada mata pelajaran Simulasi Digital sebesar 90,63\%, sehingga tingkat efektifitasasnya dapat di interprestasikan sangat baik digunakan.

2. Saran

a. Bagi para perancang dan pembuat perangkat pembelajaran, diharapkan melakukan perancangan yang terancana dan terstruktur.

b. Lakukanlah pengembangan dan perbaikan terhadap isi Mobile Learning berbasis client sever secara berkala, sehingga materi yang disampaikan dapat di sesuaikan dengan kebutuhan dan tuntutan kurikulum. 


\section{Referensi}

[1] Wina Sanjaya, MEDIA KOMUNIKASI PEMBELAJARAN. Jakarta: Kencana Prenada Media Group, 2012.

[2] S. R. Wijaya Indra, "Interactive Multimedia CD Design Chemistry Lesson In Concept Training Material and amendment For Class X Vocational High School (SMK)," J. Dyn., vol. 1, no. 1, 2016.

[3] I. Sefriani, Rini. Wijaya, "INTERACTIVE MULTIMEDIA LEARNING MODULE BASED ON ADOBE DIRECTOR ON OPERATION SYSTEM COURSE ON VOCATIONAL HIGH SCHOOL," INTECOMS, vol. 1, no. 1, 2018.

[4] L. Yuniati, "Pengembangan Media Pembelajaran Mobile Learning Efek Doppler Sebagai Alat Bantu Dalam Pembelajar- an Fisika Yang Menyenangkan," $J P 2 F$, vol. Vol. 2., no. No. 2., 2011.

[5] A. Arsyad, Media Pembelajaran. 2011.

[6] indra \& S. rini Wijaya, "INTERACTIVE MODULES BASED ADOBE DIRECTOR ON COMPUTER ASSEMBLING SUBJECTS FOR VOCATIONAL SECONDARY SCHOOL," volt Pendidik. elektro, vol. 2, 2017.

[7] L. Rahmelina, S. Informasi, and S. Operasi, "PERANCANGAN MOBILE LEARNING BERBASIS ANDROID PADA," vol. 11, no. 2, pp. 1-7, 2017.

[8] Sugiyono, Metode Penelitian Kuantitatif, kualitatif dan R \& D. 2013.

[8] Penelitian dan Pengembangan .http://Penelitian dan Pengembangan Magfirah_fhira91.html(diakses25/09/2015,12.15 wib)

[9] Purwanto.2010.Pengertian Efektifitas (diakses 20 April 2015). http://id.shyoong.com/ businnesmanagement/human-resources/pengertian efektifitas//

[10] Rusman. 2003. BelajardanPembelajaranBerbasisKomputer: Mengembangkan Guru abad 21. Bandung: Alfabeta

[11] Satrio. 2008. Pengertian Efektifitas (diakses 20 April 2015). http://id.shyoong.com/ businnesmanagement/human-resources/pengertian efektifitas//

[12] Thiagarajan, dkk.1974.Instructional Development forTraining Teachers of Expectional Children.Minneapolis,Minnesota:Leadership Training Institute/Special Education,University of Minnesota.(https://bustangbuhari.wordpress.com/2011/08/25/four-d-model-model-pengembanganperangkat-pembelajaran-dari -thiagarajan-dkk.di akses 19/01/2016 pukul 19.44 wib) 